\title{
The Implementation of Zapira Portable by Maximizing the Potential Source in Rural Area
}

\author{
Ika Febriana Wati \\ Elementary and Preschool Education Department \\ State University of Malang, Indonesia \\ febrianabiebs6@gmail.com
}

Eka Ajeng Fabela

Elementary and Preschool Education Department

State University of Malang, Indonesia

ekaajengfabela@gmail.com

\author{
Yunita Miftahul Jannah \\ Elementary and Preschool Education Department \\ State University of Malang, Indonesia \\ yunitamiftahuljannah486@gmail.com \\ Yuniawatika \\ Elementary and Preschool Education Department \\ State University of Malang, Indonesia \\ yuniawatika.fip@um.ac.id
}

\begin{abstract}
The electrification ratio in Indonesia reached 98.3\%. Power plant technology innovations are needed, is it can be applied in rural areas with more environmentally friendly energy sources. One of them is rainwater. This is supported by the average rainfall in Indonesia which is quite high, which is $1000-4000 \mathrm{~mm} / \mathrm{year}$. The right innovation to be applied in the rural area is Zapira Portable. Zapira Portable is a portable scale household power plant that utilizes potential rainwater energy as a source of energy. The purpose of this activity program is 1 ) to create a device with potential rainwater energy generation, 2) to create portable power plants for household scale, and 3) to maximize electricity distribution in the 3T area. Implementation methods of Zapira Portable development include: 1) literature study, 2) design, 3) analysis of equipment and material requirements, 4) making devices, 5) implementation, 6) determination based on the results of implementation tests, and 7) evaluation. The results achieved are in the form of Zapira Portable device design, Zapira Portable device, video from device usage, Manual Book of Zapira Portable, validation of Zapira Portable devices, and testimonials.
\end{abstract}

Keywords: implementation, zapira portable, potential source, rural area

\section{INTRODUCTION}

Community life cannot be separated from electricity. Based on data from the National Electricity Company in 2018 on its website www.pln.co.id, more than 3,660 villages in Indonesia have not yet been electrified. The shortcomings in electricity distribution mostly occur in the Foremost, Outermost, Disadvantaged (rural area) regions. Reporting from data from the Ministry of Energy and Mineral Resources, the electrification ratio in Indonesia reached 98.3\%.

The government conducts electricity distribution through the use of coal as the main material for electricity generation. However, this effort has a negative impact in the form of air pollution, public health problems, and environmental damage. Power plant technology innovations are needed that can be applied in 3T areas with more environmentally friendly energy sources. One of them is rainwater. This is supported by the average rainfall in Indonesia which is quite high, which is 1000 $4000 \mathrm{~mm} /$ year.

The right innovation to be applied in the rural area is Zapira Portable. Zapira Portable is a portable scale household power plant that utilizes potential rainwater energy as a source of energy. By adopting the principle of Micro-Hydro Power Plant (PLTMH), rainwater from gutters will be accommodated in a reservoir and flow rotates the turbine. This turbine rotation is processed in a generator to finally be able to produce electrical energy. The use of this technology is quite easy and abundant supply of rain energy.

In 2015, Lutfi et al, students of the Depok Cakra Buana Vocational School created a rainwater hydroelectric power plant. But the results are small and the search for material is quite difficult. Whereas in 2017, there was the idea of a Microhydro at Home Power Plant (POPMIH) by Semarang State University students. But this is still a concept and there is no actual implementation. When compared with the two previous findings as well as the Microhydro Power Plant (MHP), Zapira Portable is cheaper and easier to find its components, its function can be proven, devices are portable, and can be used for household scale. Zapira Portable which uses rainwater has the potential to become a wearable, portable and free energy power plant. It is expected that this tool can maximize electricity distribution in the rural area and can be operated by anyone.

The purpose of this activity program is 1) to create a device with potential rainwater energy generation, 2) to create portable power plants for household scale, and 3) to maximize electricity distribution in the rural area.

\section{METHOD}

The method for implementing the Zapira Portable development program is as follows.

\section{A. Literature Study}

Literature studies are carried out to update facts in the field and minimize the risk of device dysfunction. The literature study was carried out by observing the electrical installation conducted at the Surabaya State Shipping Polytechnic. To strengthen the determination of components, the team conducted consultations with mechanical and electrical experts, namely Ms. Amal Ma'rifatul Maghfiroh from Bojonegoro University. 


\section{B. Design}

Zapira Portable is designed with a shape that can be assembled and can be placed in all buildings that have gutters. There are two main parts of the device design, namely the pipe-shaped outer part of the device to be placed in the rain water channel and the inner device which is packaged in a beam-shaped box measuring about $30 \mathrm{~cm} \times 20 \mathrm{~cm} \times 15 \mathrm{~cm}$.

\section{Analysis of Tools and Data}

Based on the analysis of the tools that have been carried out, the Zapira Portable device consists of material tools and materials according to Table I as follows.

Table I

Tools and materials.

\begin{tabular}{|c|c|c|}
\hline Materials & Details & Qty \\
\hline Turbine & 12 Blade & 1 \\
\hline Pipe & PVC, T-Shape, diameter 2,5 dim & 1 \\
\hline $\begin{array}{l}\text { Motor } \\
\text { Generator }\end{array}$ & $\begin{array}{l}\text { - DC tipe } 77512 \mathrm{~V} \\
\text { - Motor Diameter: } 44.8 \mathrm{~mm} \\
\text { - Motor Length: } 72 \mathrm{~mm} \\
\text { - Output Shaft: } 5 \mathrm{~mm} \\
\text { - Output Length: } 21 \mathrm{~mm} \\
\text { - Screw Hole: M4 } \\
\text { - Screw Pitch: } 29.5 \mathrm{~mm} \\
\text { - Weight: } 446 \text { gram } \\
\text { - Speed: } 400 \mathrm{RPM} \\
\text { - Current: } 1.8 \mathrm{~A} \\
\end{array}$ & 1 \\
\hline Controller & $\begin{array}{l}\text { - Type PMW } \\
\text { - Available ports for generators, } \\
\text { batteries, and loads } \\
\text { - Available buttons and LCD display }\end{array}$ & 1 \\
\hline Voltmeter & Digital & 1 \\
\hline Dry Battery & $12 \mathrm{~V} 7.2 \mathrm{Ah}$ & 1 \\
\hline Banana plug & - & 10 pairs \\
\hline LED & DC 12 V 3 Watt $0.25 \mathrm{~A}$ & 5 \\
\hline Acrylic & Milky white, thick $5 \mathrm{~mm}$ & $3 \mathrm{~m}^{2}$ \\
\hline Brass & Hinges & 2 \\
\hline
\end{tabular}

In addition to analyzing tools and materials, data analysis was also carried out. Data from BMKG, the average rainfall in Indonesia is $5-8 \mathrm{dm} 3 /$ minute. The majority of the roofs of houses in Indonesia are in the form of prisms with their sides divided into 2 equal widths with one gutter on each side. The average roof area in Indonesia ranges from $36-120 \mathrm{~m} 2$. If averaged, the roof area is $78 \mathrm{~m} 2$, so one side of the roof of the house ranges from $39 \mathrm{~m} 2$. If the area of the roof that flows rainwater to the gutters is considered to be a crosssectional area, then the water discharge on the gutter to fill the reservoir can reach 195-312 dm3/minute with the following calculation.

$\mathrm{Q}=\mathrm{V} \times \mathrm{A}(\mathrm{V}=$ Rainfall, $\mathrm{A}=$ Cross-Section Area $)$

$\mathrm{Q}=5 \mathrm{~s} / \mathrm{d} 8 \times 39$

$\mathrm{Q}=195 \mathrm{~s} / \mathrm{d} 312 \mathrm{dm} 3 / \mathrm{m}=3,25 \times 10-3 \mathrm{~m} 3 / \mathrm{s} \mathrm{s} / \mathrm{d} 5,2 \times 10-3$ $\mathrm{m} 3 / \mathrm{s}$

The potential power that can be generated from the Zapira Portable device is influenced by the water discharge (m3 / s) and head (the height of the fall of water) $(\mathrm{m})$. If the head is $1.5 \mathrm{~m}$, the power potential reaches 1.16 to 1.86 Watts per second according to the calculation as follows.

$\mathrm{P}=\eta \times \mathrm{g} \times \mathrm{Q} \times \mathrm{h}$

$\mathrm{P}=0,95 \times 9,8 \times 8,3 \times 10-5 \mathrm{~s} / \mathrm{d} 1,3 \times 10-4 \times 1,5$

$\mathrm{P}=1,16 \times 10-3 \mathrm{~s} / \mathrm{d} 1,86 \times 10-3 \mathrm{~kW}=1,16 \mathrm{~s} / \mathrm{d} 1,86 \mathrm{Watt}$.
D. Making a Device

Making the device starts with print designs, then install pipes, install turbines with generators in pipes, make storage boxes, make generator sockets and load, install digital voltmeter, connect components with the controller, and install dry batteries.

\section{E. Implementation}

The Zapira Portable device is designed to be installed on rainwater pipes or gutters. Gutter can be modified to obtain maximum water discharge by applying the principle of velocity. The lower part of the gutter is added to the water reservoir so that the water discharge coming out to the Zapira Portable pipe remains stable. Implementation is done by installing a Zapira Portable device in a house building. If the season does not support the occurrence of rain, the device can be used in a place that has a type of water flow with the discharge of rainwater from gutters.

\section{F. Test Results}

The test results obtained from the calculation of the power generated based on time, rainwater discharge, and rotation on the generator. The use of maximum power is also a consideration of tool evaluation later. If the test results meet the feasibility, the device is ready to be massproduced to achieve its purpose as an electricity distribution device.

\section{G. Evaluation}

Evaluation includes tool functionality, tool effectiveness, tool shortcomings, tool development potential. Evaluation is obtained after the tool has been implemented and through the calculation process to get the test results.

\section{RESULTS}

The results achieved in accordance with the development of Zapira Portable are as follows.

\section{A. Design}

In the design of the device there are 7 main components (figure 2) that make up the device. These parts include 1) T PVC pipe, 2) turbine, 3) 12 volt DC generator, 4) power storage packaging box, 5) PMW type controller, 6) dry battery, 7) digital voltmeter.

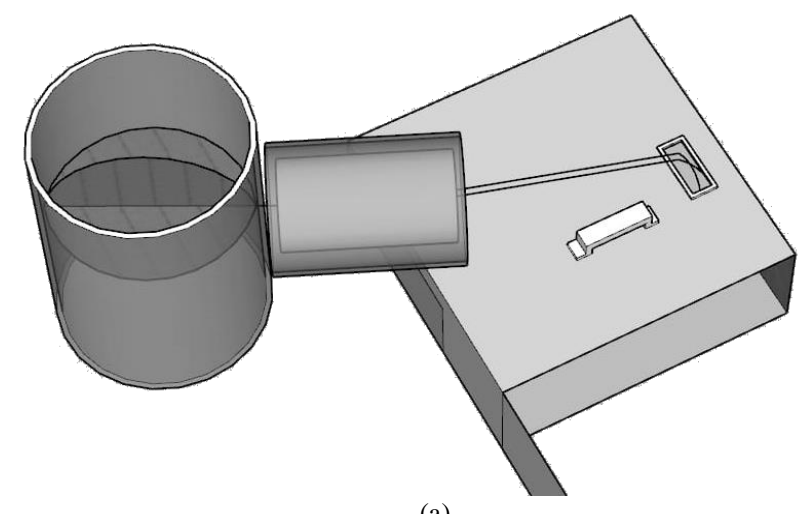

(a) 


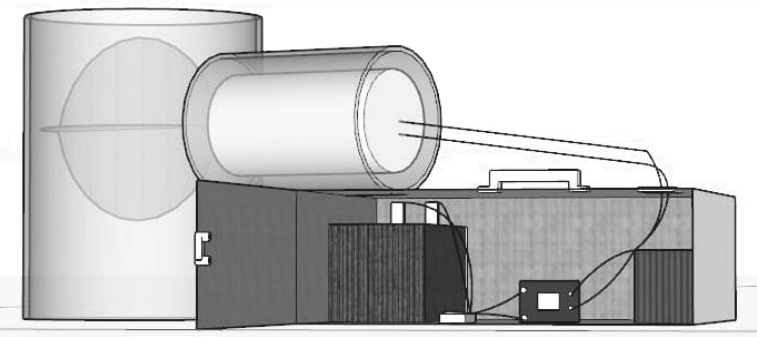

(b)

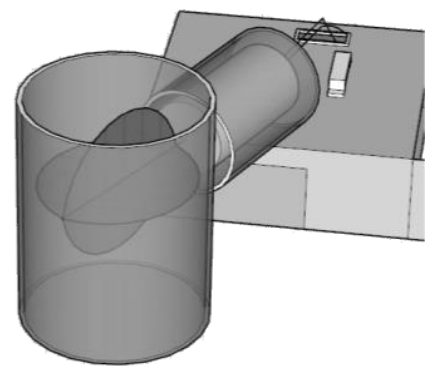

(c)

Figure 1. Top view design (a), front view (b), side view (c)

Zapira Portable installation is located under the rainwater drain pipe or commonly called gutters. Effective waterway design to optimize the performance of Zapira Portable is a gutter that is horizontal along the end of the roof leading to a pipe under which a water reservoir is installed. Zapira Portable is installed on a pipeline under the reservoir. It is intended that the rain water that rotates the turbine has a stable discharge.

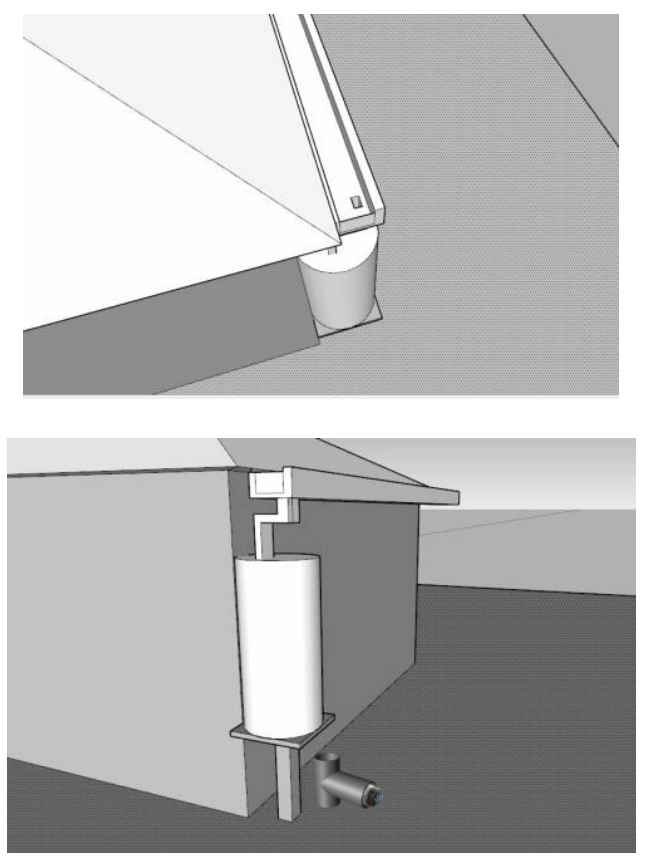

Figure 2. Device Installation Design

\section{B. Zapira Portable Device.}

The device is made based on the design that has been made. The outer circuit is in the form of a $\mathrm{T}$ pipe with a size of about $20 \times 15 \times 8 \mathrm{~cm}$. Whereas box packaging has a storage capacity of $30 \times 20 \times 15 \mathrm{~cm}$.

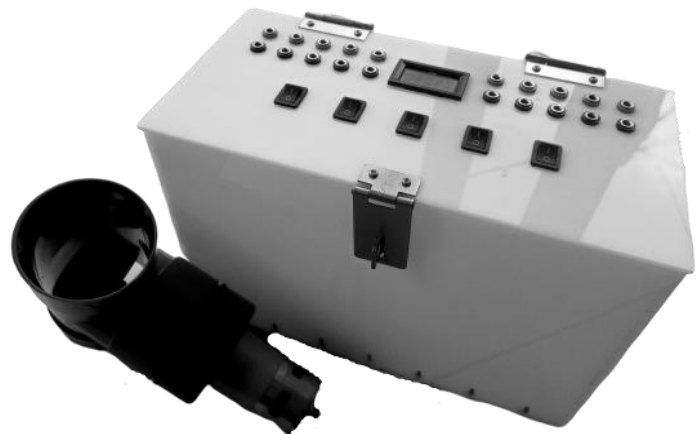

Figure 3. Zapira Portable Device

The way Zapira Portable works starts from water that falls on gutters with a height from the roof of about $1.5 \mathrm{~m}$ and has a flow of about 5 to $8 \mathrm{dm} 3$ / minute. This water will drive the generator. The power that enters through the PMW controller will be stabilized so that the voltage entering the battery is stable. Through this controller you can also calculate the amount of power and voltage in the battery so that it can disconnect the incoming current automatically when it is fully charged.

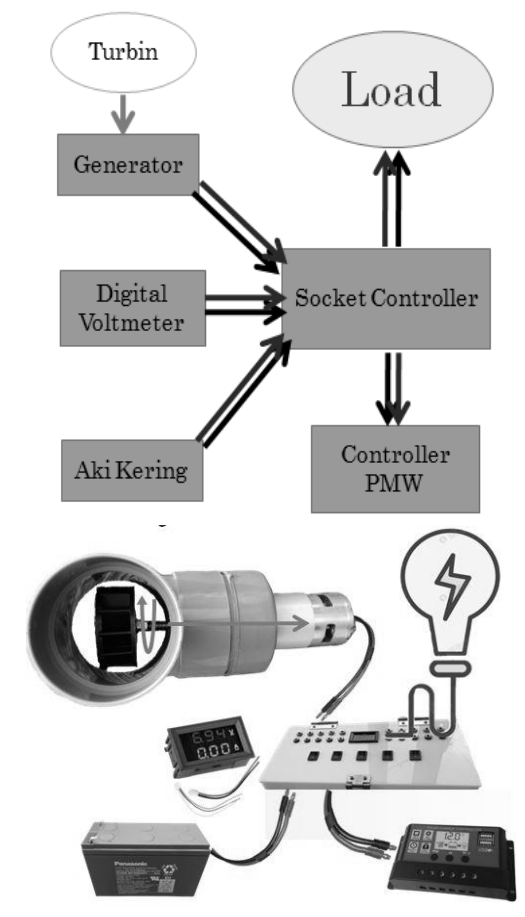

Figure 4. Working Scheme of Zapira Portable

\section{Video of Device Usage}

The device video shows a tutorial from the operation of Zapira Portable. This video can be an overview of how the device works. This video can also be proof of the functioning of the device.

\section{Manual Book of Zapira Portable}

The manual book contains steps to operate the device.fonts are prescribed; please do not alter them. You may note peculiarities. For example, the head margin measures proportionately more than is customary. This 
measurement and others are deliberate, using specifications that anticipate your paper as one part of the entire proceedings, and not as an independent document. Please do not revise any of the current designations.

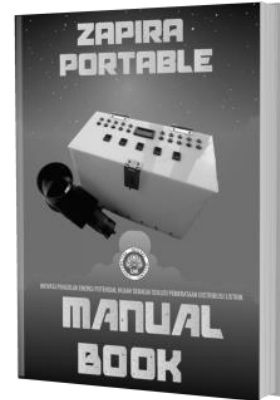

Figure 5. Manual Book of Zapira Portable

\section{E. Validation of the Zapira Portable Device}

Validation is needed to strengthen the device in design and function. Some of these experts include the East Java ESDM Service, PT. PLN East Java Unit, and BMKG Malang.

\section{F. Testimonials of Zapira Portable Devices}

Testimonials are needed to find out the opinions of people who feel the benefits directly. The testimony that has been done is towards the community represented by the Chairperson of RW / RT 01/01 in Ngadi Village, Kediri and the Village Head of Semen, Blitar.

\section{DISCUSSION}

Based on the analysis of the results of the data, it is obtained the voltage and current that influence the amount of power produced by the Zapira Portable device. The factor that distinguishes the results of this implementation test is the water debit. From the calculation of the results, it can be seen how long the battery is needed to fill up the battery.

Table II

Implementation results

\begin{tabular}{|c|c|c|c|c|c|}
\hline Exp. & $\begin{array}{c}\text { Voltage } \\
(\mathbf{V})\end{array}$ & $\begin{array}{c}\text { Influx } \\
(\mathbf{I})\end{array}$ & $\begin{array}{c}\text { Debit } \\
(\mathbf{Q})\end{array}$ & $\begin{array}{c}\text { Potency } \\
(\mathbf{P})\end{array}$ & $\begin{array}{c}\text { Battery } \\
\text { Charging } \\
\text { Time (h) }\end{array}$ \\
\hline 1 & $1,9 \mathrm{~V}$ & $1 \mathrm{~A}$ & $8 \mathrm{ltr} / \mathrm{m}$ & 1,9 watt & 4,55 hours \\
\hline 2 & $1,7 \mathrm{~V}$ & $1 \mathrm{~A}$ & $6 \mathrm{ltr} / \mathrm{m}$ & 1,7 watt & 5,1 hours \\
\hline 3 & $1,4 \mathrm{~V}$ & $1 \mathrm{~A}$ & $4 \mathrm{ltr} / \mathrm{m}$ & 1,4 watt & 6,15 hours \\
\hline
\end{tabular}

Based on the specifications of the battery, it can be known that the usage time is in accordance with the power released. The battery specifications used in Zapira Portable are Panasonic dry batteries. 12 V LCV127R2NA DC, 7.2 Ah / $20 \mathrm{HR}$. Suppose that the battery is only loaded with a 3 watt / 12 V DC LED light, so the battery usage time is as follows.

Known:

$\begin{array}{lll}\text { Load } & \text { (P) } & =3 \text { watt } \\ \text { Then, } \quad(\mathrm{V}) & =12 \mathrm{~V} \\ \mathrm{I} & =\mathrm{P}: \mathrm{V} \\ & =3: 12 \\ \mathrm{I} & =0,25 \mathrm{~A}\end{array}$

Usage Time $(\mathrm{h})=\mathrm{Ah}: \mathrm{I}$

$$
\begin{aligned}
& =7,2 \text { Ah }: 0,25 \mathrm{~A} \\
& =28,8 \text { hours } \\
& =28,8 \text { hours }- \text { battery deficiency }(20 \%) \\
& =28,8 \text { hours }-5,76 \text { hours } \\
& =23,04 \text { hours }
\end{aligned}
$$

So, the usage time for 3 watt /12 V DC LED lights is 23 hours 2 minutes 24 seconds.

\section{CONCLUSION}

Based on the results of testing, Zapira Portable is able to turn up to 5 loads. This is also what determines the number of sockets on the controller. Zapira Poertable is appropriately applied in Indonesia because the required water discharge is in accordance with the rainfall in Indonesia, which is 4-8 liters/minute. The potential power generated is also quite large, which is up to 1.9 watts. This is what makes Zapira Poertable feasible to be a solution to the lack of electricity distribution in rural areas.

\section{ACKNOWLEDGMENT}

Gratitude to Allah subhanahu wa ta'ala for giving His mercy so that we can finish the development and this article nicely. Thank you to the Ministry of Research, Technology and Higher Education for their trust in funding the development of the Zapira Portable device. Thank you to all the officials of the State University of Malang for their support and opportunities. Thank you to the experts who are the validators and sources of liturgical studies. And thanks to the people who have shown support through testimonials from the Zapira Portable device.

\section{REFERENCES}

[1] Anuar.Khairil., dkk. 2015.Analisis Kualitas Air Hujan Sebagai Sumber Air Minum Terhadap Kesehatan Masyarakat(Studi Kasus di Kecamatan Bangko Bagansiapiapi).Jurnal Dinamika Lingkungan Indonesia. Vol. 2, No. 1, hh. 32-39.

[2] Ceri Steward Poea, G.D. Soplanit \& Jotje Pantung. 2013. Perencanaan Turbin Air Mikro Hidro Jenis Pelton untuk Pembangkit Listrik di Desa Kali Kecamatan Pineleng dengan Head 12Meter. Manado: Universitas Sam Ratulangi.

[3] Fox \& Mc Donald. 2011.Introduction to Fuild Mechanic, Eight Edition SI Version. Singapura: John Wiley \& Sons,Inc.

[4] Irawan,Heri., dkk. 2018. Analisis Performansi Sistem Pembangkit Listrik Tenaga Air Jenis Turbin Pelton Dengan Variasi Bukaan Katup Dan Beban Lampu Menggunakan Inverter.Jurnal Hasil Penelitian. Vol. 3, No. 1, hh. 27-31.

[5] Juwito, A. F., dkk. 2012.Optimalisasi Energi Terbarukan padaPembangkit Tenaga Listrik dalam Menghadapi Desa Mandiri Energi di Margajaya.Jurnal Ilmiah Semesta Teknika.Vol.15, No. 1, hh. 22-34.

[6] Kementerian Energi dan Sumber Daya Mineral Republik Indonesia. 2018.Menteri ESDM: 98,3\% Penduduk Sudah Menikmati Listrik.https://www.esdm.go.id. diakses pada tanggal 12 November 2018.

[7] Lampiran Peraturan Menteri Negara Lingkungan Hidup No. 12 Tahun 2009.

[8] PT PLN (Persero). 2018. RUTL PT PLN (Persero)2018-2027. https://www.pln.co.id. Jakarta: PT PLN (Persero).

9] Samsul, Kamal \& Prajitno.2013.Evaluasi unjuk kerja turbin air pelton terbuat dari kayu dan bambu sebagai pembangkit listrik ramah lingkungan untuk pedesaan.Jurnal Manusia dan Lingkungan, Vol. 20, No. $\quad 2, \quad$ hh.190-198. 